\title{
PERGESERAN MAKNA DALAM KESENIAN NDOLALAK \\ DAN IMPLIKASINYA TERHADAP KEHIDUPAN \\ SOSIAL KEAGAMAAN MASYARAKAT DI PURWOREJO
}

\author{
Mahsun \\ Fakultas Syariah dan Hukum UIN Walisongo Semarang \\ Email: mahsun_mahfud@yahoo.com
}

\begin{abstract}
Abstrak
Penelitian ini dilatarbelakangi oleh asumsi adanya pergeseran makna dalam seni tari ndolalak. Awalnya ketika seni tari tersebut dikreasi mengandung pesan-pesan dakwah yang tersirat dalam lirik lagunya. Namun kenyataannya sekarang telah terjadi perubahan. Perubahan itu adalah antara lain: lirik lagu tidak lagi bernuansa dakwah, dahulu penarinya laki-laki, sekarang perempuan.

Ada tiga masalah yang dikaji yaitu: Pertama, mengapa terjadi pergeseran nilai dalam seni tari ndolalak? Kedua, faktor apa yang memengaruhi pergeseran nilai tersebut? Ketiga, apa implikasinya dalam kehidupan sosial-keagamaan masyarakat di Purworejo?

Metode pengumpulan data terdiri dari interview dan dokumentasi. Sedangkan analisisnya menggunakan metode induktif dengan menggunakan dua pendekatan yakni antropologi dan sosiologi. Dalam analisisnya, menggunakan teori Clifford Geertz yakni teori simbol/pergeseran nilai, untuk menganalisa pergeseran nilai dan faktor yang mempengaruhi; dengan memposisikan tari ndolalak sebagia sebuah simbol yang di dalamnya tersimpan nilai-nilai. Sementara analisis implikasi sosialnya menggunakan teori dialektika sosialnya Peter L. Berger.

Temuannya adalah pertama, terjadi pergeseran nilai dalam seni tari ndolalak karena adanya tarik menarik antara etika/norma dan estetika dalam memahami seni. Kedua, ada 2 faktor yang memengaruhi pergeseran nilai tersebut yaitu faktor intrinsik terdiri dari SDM, keindahan (beanty), gerakan dan lirik lagu. Dan faktor ekstrinsik meliputi ekonomi, dinamika sosial, paham keagamaan, intervensi pemerintah, maraknya musik orgen tunggal dan dangdut. Ketiga, implikasi sosialnya adalah terjadi pro dan kontra terhadap eksistensi seni tersebut terutama setelah muncul fatwa haram dari MUI Purworejo tahun 1985.
\end{abstract}


Keywords: dialektika, estetika, etika, nilai, seni

\section{Latar Belakang Masalah}

Manusia adalah makhluk berbudaya dalam arti ia selalu mengolah diri dan lingkungannya sepanjang perjalanan hidupnya dan dalam menjalani hidupnya. Ia mesti mewarisi banyak hal dari generasi-genarasi yang datang sebelumnya seperti cara bekerja, sopan santu, cara memelihara diri dan cara menyelesaikan persoalan, serta cara mengapresiasi kehidupan dan menuangkan dalam sebuah karya seni tentunya. ${ }^{1}$

Seni merupakan proses kreativitas manusia, yang berasal dari ide, gagasan, luapan perasaan yang diekspresikan melalui media tertentu, sehingga orang lain dapat turut menikmatinya dan dapat turut mengapresiasi pesan yang disampaikan oleh pembuat karya seni tersebut. Manusia sangat erat dengan pesan-pesan, yang diteruskan dari satu generasi ke generasi berikutnya. Melalui seni, manusia mewariskan pesanpesan kehidupan, sebuah kebijaksanaan untuk menghadapi tantangan dan menyelesaikan problem kehidupan. Metafora alam misalnya, dapat diceritakan dengan penuh pesona dalam sebuah cerita legenda, ataupun diterjemahkan ke dalam tari-tarian, nyanyian, drama, dan sebagainya. ${ }^{2}$

Seni adalah produk budaya manusia yang usianya sudah sangat tua, seumur dengan peradaban manusia. Memang tidak semua karya seni mengalami nasib yang baik untuk bisa sampai di tangan generasi masa kini, sebagian rusak tidak terawat, bahkan sebagian dimusnahkan karena alasan tertentu. $^{3}$

Namun, seni terus mengalir dari generasi ke generasi, memperbaharui bentuknya yang kontekstual terhadap jaman. Misalnya, lakon Odiesus yang tersohor dari jaman Yunani kuno, hingga masa kini

1 Machasin, Islam Dinamis Islam Harmonis Lokalitas, Pluralisme, Terorisme, cet.I (Yogyakarta: LKiS, 2012), hlm. 185.

${ }^{2}$ Lihat David Ardes Setiady, "Pengaruh Seni Dalam Hidup Manusia" dalam http://proaktif-online.blogspot.com/2013/12/pikir-pengaruh-seni-dalam-hidupmanusia.html

${ }^{3}$ Ibid. 
kerap dipentaskan oleh grup-grup teater. Ataupun, cerita Romeo dan Juliet yang hingga hari ini menjadi simbol kisah percintaan yang tragis. Karya seni tersebut berjalan menembus ruang dan waktu, mendapatkan tempatnya di hati generasi masa kini. ${ }^{4}$

Adat dan tradisi serta kebudayaan yang telah diterima oleh masyarakat dan telah terinternalisasi dalam diri mereka akan menjadi karakternya. Sedangkan fungsi nilai yang terkandung di dalam budaya dan kebudayaan mempunyai implikasi yang lebih efektif dibanding dengan kontrol lembaga formal yang hingga kini konsepnya belum jelas. ${ }^{5}$

Kebudayaan merupakan kata berimbuhan dari kata dasar "budaya". Budaya atau kebudayaan berasal dari bahasa Sansekerta yaitu "budayyah", yang merupakan bentuk jamak dari "buddhi" (budi atau akal), diartikan sebagai hal-hal yang berkaitan dengan budi dan akal manusia. Dalam bahasa Inggris, kebudayaan disebut dengan "culture" yang berasal dari bahasa Latin "colere", yang berarti mengolah atau mengerjakan. Dalam bahasa Indonesia, "culture" sudah menjadi kata serapan yaitu kultur. ${ }^{6}$

Kebudayaan sangat erat kaitannya dengan masyarakat. Melville J. Herskovits dan Bronislaw Malinowski mengemukakan bahwa segala sesuatu yang terdapat dalam masyarakat ditentukan oleh kebudayaan yang dimiliki oleh masyarakat itu sendiri. Dalam kehidupan sehari-hari dapat disaksikan bahwa segala upaya yang dilakukan manusia untuk menemukan dan menciptakan suatu inovasi, merupakan proses dan hasil dari budaya. Menurut Andreas Eppink, kebudayaan mengandung keseluruhan pengertian nilai sosial, norma sosial, ilmu pengetahuan serta keseluruhan struktur-struktur sosial, religius, segala penryataan intelektual dan artistik yng menjadi ciri khas suatu masyarakat. ${ }^{7}$

Sedangkan Ki Hajar Dewantara, mengartikan kebudayaan sebagai

${ }^{4}$ Ibid.

5 Ridwan Hasan, "Seni Seudati: Media Edukasi Sufistik dalam mengembangkan nilai Socio-Religius Masyarakat Aceh", dalam al-Tahrir Jurnal Pemikiran Islam, Vol. 13, No. 1 Mei 2013, hlm. 153.

${ }^{6}$ Lihat https://karyatulisilmiah.com/pengaruh-budaya-terhadap-lingkungan/. Diakses 25-10-2017.

${ }^{7}$ Ibid. 
buah budi manusia yang merupakan perjuangannya terhadap dua pengaruh kuat, yaitu zaman dan alam yang merupakan bukti kejayaan hidup manusia untuk mengatasi berbagai macam rintangan dan kesukaran dalam hidup. ${ }^{8}$ Perwujudan dari kebudayaan adalah produk-produk yang diciptakan oleh manusia, berupa perilaku dan benda-benda yang bersifat nyata, misalnya pola-pola perilaku, bahasa, peralatan hidup, organisasi sosial, religi, seni, dan lain-lain. Semuanya itu ditujukan untuk membantu manusia dalam melangsungkan eksistensi kehidupan bermasyarakat. ${ }^{9}$

Dengan demikian, kebudayaan merupakan suatu yang bisa memengaruhi tingkat pengetahuan yang meliputi ide atau gagasan yang terdapat dalam pikiran manusia, sehingga dalam kehidupan sehari-hari kebudayaan itu bersifat abstrak. Namun, kebudayaan dapat dilihat dari perilaku dan benda-benda yang bersifat nyata yang ada di lingkungan masyarakat sebagai wujud ciptaannya sebagai makhluk yang berbudaya. ${ }^{10}$

\section{Rumusan Masalah}

Ada tiga masalah pokok yang menjadi fokus penelitian yaitu:

1. Mengapa terjadi pergeseran nilai dalam seni tari ndolalak?

2. Faktor apa yang memengaruhi pergeseran nilai tersebut?

3. Apa implikasinya dalam kehidupan sosial-keagamaan masyarakat di Purworejo?

\section{Kerangka Pemikiran dan Landasan Teori}

Dalam konteks pemahaman terhadap makna, manusia menjadi faktor penentu dengan melalui pandangan dan pengetahuannya. Sesuatu yang baik bisa menjadi sebaliknya jika manusia menghendakinya. Agama misalnya, adalah sesuatu yang baik menjanjikan kebahagiaan. Namun seringkali justru agama diperankan oleh manusia sebagai alat untuk menindas, ketidakadilan, keterkungkungan, dan sebagainya.

Dalam konteks budaya, karya seni juga bisa dimaknai dan

${ }^{8}$ fadila-hasnan93.blogspot.com. Diakses ulang pada tanggal 25-10-2017

${ }^{9}$ Ibid.

${ }^{10}$ Ibid.

Mabsun, Pergerseran Makna Dalam Kesenian ... 
dimainkan perannya oleh manusia secara dinamis. Artinya karya seni semisal seni tari dapat dimaknai secara baik sehingga menghasilkan nilai baik, begitu pula sebaliknya.

Secara garis besar terjadinya pergeseran makna dalam seni tari ndolalak (sebagai variabel bebas) secara langsung maupun tidak langsung mempunyai pengaruh terhadap kehidupan sosial keagamaan masyarakat Purworejo (sebagai variabel terikat). Pengaruh tersebut disebabkan adanya faktor intrinsik yaitu perbedaan pemahaman keagamaan masyarakat Purworejo terhadap karya seni ndolalak dalam perspektif hukum Islam. Sebagian ulama sebagai representasi masyarakat muslim seperti $\mathrm{KH}$. Abdullah Syarqowi dan KH. Moh. Asnawi Dahlan mengatakan bahwa tarian tersebut haram hukumnya baik dari sisi pakaian, penari wanita maupun cara melakukannya karena memperlihatkan lekukan-lekukan badannya yang dapat menimbulkan nafsu birahi.

Disamping faktor intrinsik, ada bebarapa faktor ektrinsik yang juga mempengaruhi pergeseran nilai yang kemudian secara sosiologis mempengaruhi kehidupan sosial masyarakat Purworejo. Faktor tersebut terbagi menjadi tiga dilihat dari cakupan konteksnya. Yang pertama adalah faktor mikro yaitu ekonomi dan pasar. Pada awalnya ketika seni tari ndolalak hanya murni sebagai hiburan, dan penarinya kaum laki-laki, syairnya berupa nasehat, dan bacaat selawat, tidak menimbulkan ekses apa-apa sehingga makin digandrungi oleh masyarakat Purworejo. Namun karena faktor ekonomi dan pasar, seni tari tersebut berubah menjadi pertunjukan yang bersifat komersial. Akibatnya tampilan seni tersebut cenderung mengikuti permintaan pasar, sehingga penari yang tadinya lakilaki diganti wanita dengan alasan wanita lebih menarik para kaum laki-laki sebagai mayoritas penontonya.

Faktor kedua yaitu konteks meso yakni kearifan lokal (local wishdom) yang juga mempengaruhi empat variabel sebelumnya. Salah satu contohnya adalah kreasi dalam tampilan pakaian yang dulu di atas lutut, sekarang setelah ada fatwa MUI Purworejo menjadi di bawah lutut. Lagunya telah dikomodeifikasi dengan lagu-lagu Jawa dan bahkan lagu dangdut. Isi liriknya tidak hanya nasehat mengikuti pakem lagu dandang gulo tetapi juga yang lain seperti lirik lagu dangdut sesuai dengan permintaan pasar (pengundangnya) bahkan kadang-kadang disertai saweran.

Sedangkan faktor ekstrinsik yang ketiga adalah budaya Barat yang mempengaruhi tarian tersebut mulai dari cara berpakaian yang minimalis, 
kapitalisasi, dan pragmatisme, dan mencari kepuasan hawa nafsu tampak pengaruhnya terhadap ndolalak. Akibatnya muncul kesan upaya mengekploitasi tubuh wanita untuk dikomersilkan demi memuaskan penonton. Inilah yang kemudian menimbulkan pro dan kontra terhadap pertunjukan tari tersebut.

Lebih jelasnya dapat dilihat pada diagram kerangka berpikir sebagai berikut:

\section{Gambar 1 Diagram Kerangka Berpikir}

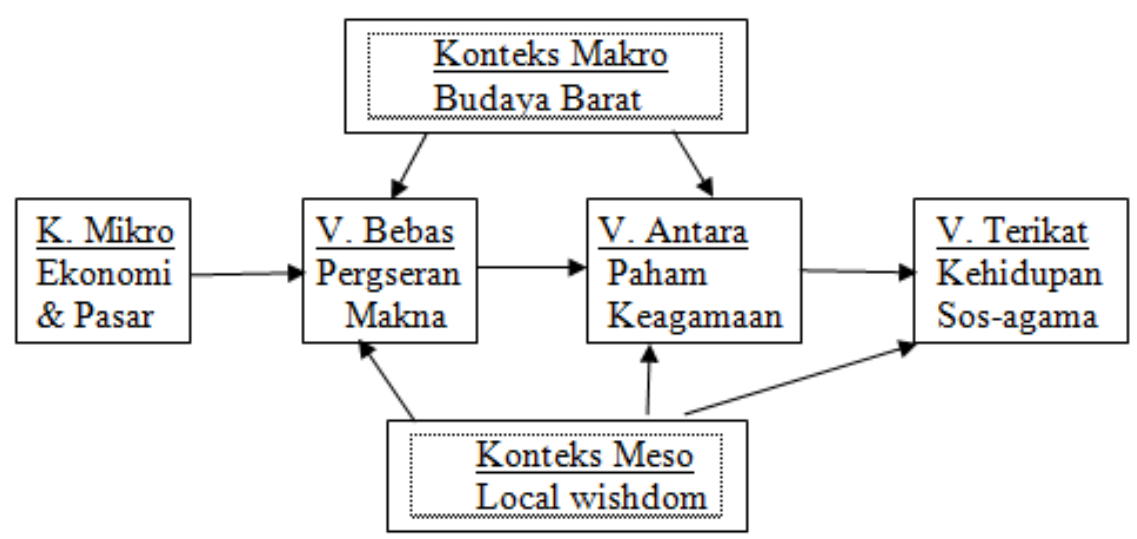

Keterangan:

1. Nomor urut menunjukkan alur berpikir

2. Tanda $\longrightarrow$ menunjukkan alur hubungan antar variabel

Manusia dalam rentang sejarahnya selalu dapat menciptakan sebuah habitus yang dilakukan secara berulang-ulang dan diyakini sebagai sebuah kabaikan. Habitualisasi prilaku manusia tersebut pada titik tertentu akan menjadi sebuah budaya. Terciptanya sebuah budaya berkorelasi sejajar dengan kehidupan manusia secara sosial. ${ }^{11}$

Budaya selalu ada kaitannya dengan agama ibarat dua sisi mata uang. Walaupun berbeda tetapi antara keduanya tak terpisahkan. Agama memberikan pedoman moral dan daya imperatif yang bersifat transenden,

11 Koentjaraningrat, Pengantar Ilmu Antropologi, cet. ke-8 (Jakarta: PT. Rineka Cipta, 1990), hlm. 1. 
yang datang dari Tuhan. Sementara budaya sesungguhnya merupakan dinamika etis kemanusiaan yang datang dari manusia. ${ }^{12}$

Agama tanpa budaya bagaikan roh tanpa tubuh. Sebaliknya budaya tanpa agama akan menjadi medan konflik para hedonis, yang pada akhirnya akan menghancurkan dirinya. Yang demikian itu terjadi karena tidak adanya nilai acuan yang bisa mengatasi keterbatasan dan absurditas pandangan hidup yang sekularistik dan nihilistik. ${ }^{13}$

Agama mempunyai misi profetis yang semestinya justru berdialog secara bijaksana dengan kenyataan sosial, untuk melakukan emansipasi dan menegakkan nilai-nilai kemanusiaan. Agama dan sikap keberagamaan bukan wilayah tertutup untuk bersenbunyi dan bersikap curiga terhadap dinamika budaya yang tidak bisa dielakkan. ${ }^{14}$

Budaya terbentuk dari sistem agama, politik, adat-istiadat, bahasa, pakaian, bangunan, dan karya seni hasil kecerdasan manusia, ${ }^{15}$ Budaya atau kebudayaan berasal dari bahasa Sanskerta yaitu buddhayah, yang merupakan bentuk jamak dari buddhi (budi atau akal) diartikan sebagai hal-hal yang berkaitan dengan budi dan akal manusia. Dalam bahasa Inggris, kebudayaan disebut culture, yang berasal dari kata Latin Colere, yaitu mengolah atau mengerjakan. Kata culture juga kadang diterjemahkan ke dalam bahasa Indonesia sebagai "kultur". ${ }^{16}$

Salah satu disiplin ilmu yang mengkaji tentang kebudayaan sebagai hasil olah pikir manusia adalah antropologi kognitif. Antropologi kognitif adalah sub bidang antropologi budaya yang mengkaji antar hubungan di antara bahasa, kebudayaan, dan kognisi. Atau dengan kata lain antropologi kognitif merupakan ancangan dalam antropologi budaya yang memandang bahwa kebudayaan sebagai kognisi manusia. Antropologi kognitif mempunyai hubungan erat dengan pandangan

12 Komaruddin Hidayat, Tragedi Raja Midas, Moralitas Agama dan Krisis Modernisme, cet. I (Jakarta: Penenrbit Paramadina, 1998), hlm. 6.

${ }^{13}$ Ibid.

${ }^{14}$ Ibid., hlm 7.

${ }^{15}$ http:// www shdcshare.net/evertstaasiringan/pengaruh-kebudayaanterhadap-perilaku-masyarakat-alaud10. Diakses 24-10-2017, Jam 5.38 wib.

${ }^{16}$ http://id.wikipedia/org/wiki/Budaya/Pengertian_kebudayaan. Diakses 24-92017, Jam 5.44 wib. 
bahwa kebudayaan berisi pikiran, mood (keinginan), perasaan, keyakinan, dan nilai-nilai yang disebut sebagai perspektif fenomenologi. ${ }^{17}$

Kebudayaan sangat erat hubungannya dengan masyarakat Melville J. Herskovits dan Bronislaw Malinowski mengemukakan bahwa segala sesuatu yang terdapat dalam masyarakat ditentukan oleh kebudayaan yang dimiliki oleh masyarakat itu sendiri. Istilah untuk pendapat itu adalah Cultural-Determinism. Herskovits memandang kebudayaan sebagai sesuatu yang turun-temurun dari satu generasi ke generasi yang lain, yang kemudian disebut sebagai superorganic. ${ }^{18}$

Menurut Andreas Eppink, kebudayaan mengandung keseluruhan pengertian nilai sosial,norma sosial, ilmu pengetahuan serta keseluruhan struktur-struktur sosial, religius, dan lain-lain, tambahan lagi segala pernyataan intelektual dan artistik yang menjadi ciri khas suatu masyarakat. Menurut Edward Burnett Tylor, kebudayaan merupakan keseluruhan yang kompleks, yang di dalamnya terkandung pengetahuan, kepercayaan, kesenian, moral, hukum, adat istiadat, dan kemampuan-kemampuan lain yang didapat seseorang sebagai anggota masyarakat. Menurut Selo Soemardjan dan Soelaiman Soemardi, kebudayaan adalah sarana hasil karya, rasa, dan cipta masyarakat. ${ }^{19}$

Dari berbagai definisi tersebut, dapat diperoleh pengertian mengenai kebudayaan adalah sesuatu yang akan memengaruhi tingkat pengetahuan dan meliputi sistem ide atau gagasan yang terdapat dalam pikiran manusia, sehingga dalam kehidupan sehari-hari, kebudayaan itu bersifat abstrak ${ }^{20}$

Perwujudan kebudayaan adalah benda-benda yang diciptakan oleh manusia sebagai makhluk yang berbudaya, berupa perilaku dan benda-benda yang bersifat nyata, misalnya pola-pola perilaku, bahasa, peralatan hidup, organisasi sosial, religi, seni, dan lain-lain, yang semuanya

${ }^{17}$ Nur Syam, Madzhab-madzhab Antropologi, Yogyakarta: LKiS, 2012, hlm. 49-50.

${ }^{18}$ http://id.wikipedia.org/wiki/Budaya\#Definisi_Budaya. Diakses ulang 24-102017, Jam 5.47 wib

${ }^{19}$ Ibid.

${ }^{20}$ Ibid.

Mahsun, Pergerseran Makna Dalam Kesenian ... 
ditujukan untuk membantu manusia dalam melangsungkan kehidupan bermasyarakat. ${ }^{21}$

Kebudayaan ditinjau dari segi tampilannya dibedakan menjadi dua yaitu kebudayaan material (benda-benda kuno, artefak, dan sebagainya), dan kebudayaan non material. Kebudayaan non material adalah ciptaan-ciptaan abstrak yang diwariskan dari generasi ke generasi, misalnya berupa dongeng, cerita rakyat, dan lagu atau tarian tradisional. ${ }^{22}$ Oleh karena kebudayaan adalah diciptakan manusia, sedangkan manusia adalah sebagai makluk yang dalam kontek sosial maupun individualnya sangat erat dengan tata nilai yang disepakati. Dengan demikian di setiap kebudayaan mengandung nilai-nilai. ${ }^{23}$

Manusia dapat mengekspresikan nilai-nilai tersebut dalam kehidupan nyata melaui pengalaman konatifnya yakni pengalaman yang dialami secara langsung dan murni. Dalam pengalaman konatif tersebut manusia mengalami pertemuan antara dia dan yang lain (the others). Misalanya pengalaman keagamaan seseorang menjadi sesuatu yang bisa direnungkan dan diekpresikan dalam bentuk sikap keberagamannya. Di sana kemudian ia akan mengenal sesuatu yang disebut nilai-nilai agama, bahasa agama, dan sikap keberagamaan. ${ }^{24}$

Agama dan juga nilai dapat dipelajari jika diletakkan pada posisi sebagai fenomena sosial yang obyektif dan tak tergantung pada pikiranpikiran individual. Ada tiga karakter yang memberi sifat obyektivitas pada

${ }^{21}$ Ibid.

${ }^{22}$ Ibid.

${ }^{23}$ Ada beberapa pengertian tentang nilai, yaitu: pertama, nilai adalah sesuatu yang berharga, keyakinan yang dipegang sedemikian rupa oleh seseorang sesuai dengan tuntutan hati nuraninya (pengertian secara umum). Kedua, nilai adalah seperangkat keyakinan dan sikap-sikap pribadi seseorang tentang kebenaran, keindahan, dan penghargaan dari suatu pemikiran, objek atau prilaku yang berorientasi pada tindakan dan pemberian arah serta makna pada kehidupan seseorang (simon,1973). Ketiga, nilai adalah keyakinan seseorang tentang sesuatu yang berharga, kebenaran atau keinginan mengenai ide-ide, objek, atau prilaku khusu (Znowski, 1974). Lihat http://adianlangge.blogspot.com/2013/05/pengertian-konsepnilai-dan-sistem.html hasil saduran dari http://www.majalahpendidikan.com/2011/04/pengertian-dan-konsep-nilai-dalamislam.html. Akses ulang 24-10-2017, Jam 5.49 wib.

${ }^{24}$ Budhy Munawar Rahman, Islam Pluralis, cet. I (Jakarta: PT. Raja Grafindo Persada, 2004), hlm. 4-5. 
agama yaitu diwariskan, bersifat umum, dan sebagai kewajiban alamiah. Meskipun tidak ada paksaan, seorang tak punya pilihan lain kecuali menerima apa yang disebut agama. Begitu pula nilai, selalu melekat dan secara terpaksa manusia tidak bisa menghindar darinya. ${ }^{25}$

Secara sosiologis agama dan nilai juga dapat dipersepsi oleh manusia sendiri. Di sini agama dan juga nilai bisa berfungsi sebagai perekat sosial dan sebaliknya bisa berfungsi sebagai pemecah kehidupan sosial masyarakat beragama. Misalnya ketika agama Yahudi dan Islam mengatakan Tuhan hanyalah satu dan satu-satunya, tidak bersekutu dan kekal. Pernyataan ini bisa dipersepsikan menyinggung agama Kristen dengan konsep Trinitasnya. ${ }^{26}$

Arkoun mengatakan, sebagaimana dikutib oleh Baedhowi, bahwa wacana agama yang sejatinya bertujuan mulia, tetapi seringkali diposisikan sebagai perisai ideologis masing-masing pemeluknya untuk menolak dan menyingkirkan "kebenaran" yang ada dalam aliran agama-agama atau budaya lain. Ekskusivitas semacam itu mengakibatkan klaim-klaim kebenaran (truth claims) yang pada akhirnya menimbulkan sistem budaya saling menyingkirkan. ${ }^{27}$

Kedudukan nilai dalam setiap kebudayaan sangatlah penting. Oleh karenanya pemahaman tentang sistem nilai budaya dan orientasi nilai budaya sangat penting dalam konteks pemahaman perilaku suatu masyarakat dan sistem pendidikan yang digunakan untuk menyampaikan sisitem perilaku dan produk budaya yang dijiwai oleh sistem nilai masyarakat yang bersangkutan. Clyde Kluckhohn mendefinisikan nilai sebagai sebuah konsepsi, eksplisit atau implisit, menjadi ciri khusus seseorang atau sekelompok orang, mengenai hal-hal yang diinginkan yang

${ }^{25}$ Evans Pritchard, Teori-teori tentang Agama Primitif, cet. I (Yogyakarta: Bagian Penerbitan PLP2M, 1984), hlm. 70-71.

26 Josep van Ess, "Muhammad in The Qur'an Propehecy and Revelation: Islamic Perspectives", dalam Hans Kung, terj. Peter Heinegg, Christianity and the World Religions: Paths of Dialogue with Islam, Hinduisme, and Buddism (USA: Willian Collins Sons \& Co., Ltd and Doubleday Inc., 1986), hlm. 6.

27 Baedhowi, Humanisme Islam: Kajian terhadap Pemikiran Filosofis Muhammad Arkoun, cet. I (Yogyakarta: Pustaka Pelajar, 2008), hlm. 205. 
mempengaruhi pemilihan dari berbagai cara-cara, alat-alat, tujuan-tujuan perbuatan yang tersedia. ${ }^{28}$

Sistem nilai budaya ini merupakan rangkaian dari konsep-konsep abstrak yang hidup dalam masyarakat, mengenai apa yang dianggap penting dan berharga, tetapi juga mengenai apa yang dianggap remeh dan tidak berharga dalam hidup. Sistem nilai budaya ini menjadi pedoman dan pendorong perilaku manusia dalam hidup yang memanifestasi kongkritnya terlihat dalam tata kelakuan. Dari sistem nilai budaya termasuk norma dan sikap yang dalam bentuk abstrak tercermin dalam cara berfikir dan dalam bentuk konkrit terlihat dalam bentuk pola perilaku anggota-anggota suatu masyarakat. $^{29}$

Sistem nilai merupakan tingkat yang paling abstrak dari adat. Suatu sistem nilai terdiri dari konsepsi-konsepsi, yang hidup dalam alam pikiran sebagian besar warga masyarakat mengenai hal-hal yang harus mereka anggap amat bernilai dalam hidup. Karena itu, suatu sistem nilai biasa berfungsi sebagai pedoman tertinggi bagi kelakuan manusia. Sistemsistem tata kelakuan manusia lain yang tingkatannya lebih konkret, seperti aturan-aturan khusus, hukum dan norma-norma, semuanya juga berpedoman kepada sistem nilai itu. ${ }^{30}$

Seni sebagai salah satu produk budaya merupakan hasil kegiatan intuisi serta pengungkapan perasaan. Groce mendekati masalah estetika dengan jalan melakukan analisis mengenai kegiatan kejiwaan, yang memberinya petunjuk pertama mengenai hakekat seni. Ia mengatakan bahwa seni merupakan kegiatan kejiwaan manusia. Ketika seni adalah kegiatan kejiwaan maka seni bukanlah obyek fisiknya. Jika seni dipandang sebagai obyek fisiknya, maka seni akan kehilangan pengaruh estetiknya. ${ }^{31}$

${ }^{28} \mathrm{Ibid}$,

${ }^{29}$ Ibid.

${ }^{30}$ Koentjaraningrat, Pengantar, hlm. 25. Lihat juga "Pergeseran Nilai Budaya Masyarakat" dalam http://aresearch.upi.edu/operator/upload/s_pkn_0705739_chapter1.pdf. Diakses 24-10-2017, Jam 5.54 wib.

${ }^{31}$ Louis O. Kattsoff, Soejono Soemargono (Penterj.), Pengantar Filsafat, cet. IX (Yogyakarta: Tiara Wacana Yogya, 2004), hlm. 371. 
Oleh karena itu memahami seni tidak bisa hanya dilihat dari tampilan formal luarannya saja tetapi sesungguhnya yang lebih substansial adalah essensi dari seni itu yakni pesan dan nilai yang terkandung di dalamnya. Memahami seni membutuhkan kearifan dan kejelian. Inilah sesungguhnya yang penting dalam melihat hakekat seni secara obyektif.

Dengan demikian sebuah karya seni seperti tari ndolalak adalah perwujudan dari sebuah kebudayaan yang didalamnya terkandung nilai. Sebagai karya seni, tari tersebut sarat dengan pesan untuk disampaikan oleh plakunya kepada penonton dalam pertunjukan. Untuk menganalisa nilai itu dapat digunakan teori simbolnya Clifford Geertz dengan memposisikan tari ndolalak sebagai sebuah simbol yang di dalamnya tersimpan nilai-nilai. Nilai-nilai itu dalam tataran tertentu akan membentuk sebuah tata nilai yang mempengaruhi kehidupan manusia.

Dalam perkembangannya, tata nilai bisa mengalami pergeseran. Pergeseran nilai itu disebabkan oleh faktor intrinsik atau faktor ekstinsik dari sebuah karya budaya seperti tari. Yang dimaksud dengan faktor intrinsik adalah faktor yang ada di dalam seni tari tersebut yaitu gerak, keindahan (beuty), dan lirik lagu yang meniringi tarian tersebut. Sedangkan yang dimaksud faktor ekstrinsik ialah faktor dari luar seni tari tersebut misalnya nilai-nilai dalam masyarakat, kondisi sosial, politik, motivasi (motivations), dan keinginan $(\text { moods })^{32}$ pencipta seni tari tersebut.

Hubungan antara budaya dan agama dapat dianalisa menggunakan teori dialektika sosialnya Peter L. Berger. Berger dan Luckman (1966/1990), memahami bahwa dunia kehidupan selalu dalam proses dialektis antara the self (individu) dan dunia sosio kultural. ${ }^{33}$ Dari dialektika tersebut akan menghasilkan produk berupa pola pikir, sikap, prilaku dan budaya.

32 Motivasi dan keinginan adalah dua hal yng dihasilkan oleh simbol-simbol keagamaan sebagai bagian dari struktur budaya. Menurut hemat peneliti, dalam konteks budaya, dua hal tersebut juga dihasilkan oleh karya seni sebagai produk budaya. Lihat Talal Asad, "The Construction of Religion as an Antropological Category”, dalam Michael Lambek (ed.), A Reader in The Antropology of Religion, cet. III (Australia: Blackwell Publishing, 2005), hlm. 118.

${ }^{33}$ Peter L. Berger, Terj. Hartono, Langit Suci Agama sebagai Realitas Sosial, cet. ke-2 (Jakarta: PT. Pustaka LP3ES, 1994), hlm. 4. 
Peter L. Berger mengatakan bahwa ada tiga tahapan dasar dalam menjelaskan proses dialektika manusia dengan lingkungan sosiokulturalnya yaitu eksternalisasi, obyektivasi, dan internalisasi. Eksternalisasi adalah suatu proses pencurahan kedirian manusia secara terus menerus ke dalam dunia baik dalam aktivitas fisik maupun mental. ${ }^{34}$ Proses tersebut hadir sebagai momen adaptasi diri manusia dengan lingkungan sosiokultural. Proses eksternalisasi yang paling mendasar adalah bagaimana individu atau subyek dengan kemampuan agensinya melakukan adaptasi terhadap teks kehidupan baik yang bersifat abstrak maupun yang bersifat konkrit. ${ }^{35}$

Dalam konteks munculnya tari ndolalak, tiga orang santri sebagai kreator tarian tersebut dengan menirukan dansa serdadu Belanda pada awalnya telah melakukan proses eksternalisasi. Proses itu diawali dengan perhatian mereka atas aktivitas para serdadu yang berdansa di sela-sela latihan untuk menghibur diri menghilangkan kepenatan latihan. Selanjutnya mereka mencoba meniru dan memodifikasi tarian tersebut dengan nada dan syair bernuansa agama. Pada saat inilah sesungguhnya adaptasi budaya Barat dengan prilaku keagamaan Islam dalam kontek sebagai budaya dimulai. yang kemudian memunculkan sebuah akulturasi.

Sebagai sebuah kegiatan hiburan, tarian serdadu Belanda (ndolala) tentu bebas nilai atau bahkan tanpa nilai karena semata-mata dilakukan sebagai kegiatan hiburan. Namun ketika tarian tersebut telah dikreas, dikonstruksi sedemikian rupa dan berakulturasi dengan budaya Islam, maka tarian tersebut menjadi sarat dengan nilai. Pada tahap inilah sesungguhnya sebuah karya budaya manusia mulai berarti dan pemakmanaannya cenderung mengikuti manusia yang mengkreasi. Akhirnya tarian tersebut sebagai karya manusia, harus muncul sebagai eksistensi baru di luar eksistensi manusia sebagai kreatornya. Inilah yang disebut tahap obyektivasi.

Tahapan yang kedua yaitu obyektivasi. Obyektivasi adalah disandangnya produk-produk aktivitas sebagai suatu realitas yang

\section{${ }^{34}$ Ibid.}

${ }^{35}$ Mahsun, "Bermazhab Secara Manhaji dan Implementasinya dalam Bahsul Masail Nahdlatul Ulama Tingkat Nasional”, Disertasi, Yogyakarta: UIN Sunan Kalijaga, 2013, hlm. 223. 
berhadapan dengan produsennya semula dalam bentuk suatu fakta eksternal terhadap para produser itu sendiri. ${ }^{36}$ Obyektivitas yang diperoleh produk-produk kultural manusia ini mengacu, baik kepada benda-benda material maupun non-material. ${ }^{37}$ Pada tahap ini sebuah karya budaya menjadi sebuah realitas yang berhadapan dengan manusia yang melahirkannya sebagai fakta eksternal yang yang mempunyai eksistensi di luar eksistensi manusia sebagai produsennya. Pada tahapan ini manusia mempunyai keleluasaan memandang karyanya dan memaknai sesuai dengan keinginannya. Sedangkan karya seni yang dihasilkan tersebut sebagai realitas obyektif yang bebas.

Sebuah karya seni yang telah terobyektivasi menjadi eksistensi eksternal dari manusia sebagai kreatornya. Pada saat itu karya seni sebagai produk budaya tampil menjadi lingkungan yang bisa mempengaruhi dan dipengaruhi oleh manusia. Pada tahapan ini antara manusia sebagai kreator dan seni tari sebagai produknya berhadap-hadapan sebagai dua entitas yang berbeda secara diametral. Masing-masing tampil sebagai eksistensinya sendiri tidak ada lagi hubungan antara keduanya.

Tahap yang ketiga adalah internalisasi. Internalisasi adalah proses penarikan kembali dunia sosial yang ada di luar diri manusia ke dalam diri manusia; dalam arti dunia sosial yang telah terobyektivasi tersebut ditarik kembali ke dalam diri manusia. Sebagai proses identifikasi diri, internalisasi merupakan momen untuk menempatkan diri di tengah kehidupan sosial sehingga menghasilkan berbagai tipologi dan penggolongan sosial yang didasari oleh basis pemahaman, kesadaran, dan identifikasi diri. ${ }^{38}$ Sesuatu yang penting dalam identifikasi diri ini adalah proses sosialisasi dan faktor lingkungan pendidikan dan sosial.

Manusia secara pelan namun pasti mencoba menarik lingkungan yang diciptakan sendiri yang telah terobyektivasi tersebut, ke dalam dirinya. Pada tahap tertentu lingkungan tersebut termasuk karya seni sebagai produk budaya manusia terinternalisasi merasuk ke dalam dirinya, sehingga tidak ada jarak antara budaya yang diciptakan dengan manusia

${ }^{36}$ Ibid. hlm. 231-232.

${ }^{37}$ Ibid. hlm. 12.

${ }^{38}$ Ibid., hlm. 276. 
yang menciptakan budaya atau kebudayaan tersebut. Ketika situasi ini telah terjadi maka akan terjadi saling mempengaruhi antara manusia dan lingkungannya.

Dalam konteks seni tari ndolalak, manusia mempengaruhi dalam bentuk kreasi dan pemaknaannya sedangkan ndolalak sebagai karya seni yang dinikmati akan mempengaruhi manusia dalam bentuk perilaku. Munculnya pro dan kontra terhadap hukum tarian tersebut dalam perspektif hukum Islam adalah salah satu dari akibat pengaruh dari dialektika antara manusia/masyarakat dengan budaya (tari ndolalake) yang sesungguhnya diciptakan oleh manusia sendiri.

Bagi ulama semisal KH. Muhajir, seorang pengasuh Pondok Pesantren Al-Amin Gintungan, Gebang, Purworejo, seni tari ndolalaki tidak selalu dipandang haram tergantung fungsionalnya. Karya seni tidak harus dibaca pada tataran tampilannya tetapi lebih essensial jika dilihat dari aspek makna dan pesan yang disampaikannnya. Senia adalah ungkapan batin yang memuat pengetahuan yang kompleks, dan mengandung keindahan essensial.

Namun bagi ulama semisal KH. Asnawi Dahlan dan MUI memandang haram hukumnya terhadap tari ndolalak. Mereka beralasan karena tarian tersebut telah memamerkan gerakan dan aurat wanita di muka umum yang bisa mengundang nafsu birahi penontonnya. Argumentasi ini tidak salah karena memang demikian adanya. Sesuai dengan larangan Allah dalam QS. Al-Ahzab, 33: 33:

$$
\text { وقرن في بيوتكن و لا تبرجن تبرج الجاهلية الأولى... }
$$

Artinya: dan hendaklah kamu tetap di rumah dan janganlah kamu berhias dan bertingkah laku seperti orang-orang jahiliyyah yang dahulu... ${ }^{39}$

Perbedaan pandapat tersebut terjadi karena adanya perbedaan sudut pandang dalam melihat sebuah karya seni tari. Ulama yang mengharamkan melihat pada aspek yang formal dan konkrit yang tampak di permukaan. Sementara bagi ulama yang tidak mempermasalahkan, melihat karya seni pada tataran substansi dan pesan serta pengetahuan yang terkandung dalam karya seni.

${ }^{39}$ Penyusun Al-Qur'an dan Terjemahnya, al-Qur'an al-Karīm wa Tarjamatu Ma'ānīhi ilā al-Lugah al-Indūisiah (Kudus: Menara Kudus, 1997), hlm.423. 


\section{Tujuan}

Sebuah penelitian mengancangkan tercapainya tujuan. Oleh karena itu tujuan penelitian harus jelas terukur sehingga memungkinkan adanya capaian. Penelitian ini bertujuan:

1. Mengetahui fenomena terjadi pergeseran nilai dalam seni tari ndolalak.

2. Mengetahu faktor-faktor yang memengaruhi pergeseran nilai tersebut?

3. Mengetahui implikasinya dalam kehidupan sosialkeagamaan masyarakat di Purworejo?

Ditinjau dari tujuannya, penelitian ini penting dilakukan dengan alasan sebagai berikut :

1. Bagi Pemerintah kabupaten Purworejo, hasil penelitian ini dapat dijadikan pertimabngan kebijakan dalam melestarikan kesenian tari ndolalak agar tidak hanya menjadi karya seni yang menghibur tetapi lebih dari itu dapat berguna sebagai sarana berdakwah dalam membina kehidupan beragama dan perbaikan moral bangsa, sehingga menjadi lebih bermakna.

2. Karena seni adalah hasil karya manusia sebagai bentuk nyata sebuah kebudayaan sangat mungkin mempunyai implikasi sosial keagamaan. Oleh karena itu penting sekali melihat implikasi atau pengaruh kesenian tari ndolalak terhadap kehidupan sosial keagamaan masyarakat di Purworejo.

Secara akademik fenomena dinamika perubahan dalam tari ndolalak dapat memperkaya khazanah keilmuan terkait dengan dialektika budaya dan agama. Keduanya saling mempengaruhi dalam kehidupan sosial keagamaan masyarakat yang budaya dan agama itu sama-sam living di masyarakat.

\section{Metodologi}

1. Jenis Penelitian

Ditinjau dari bentuk datanya yang berupa informasi, dengan paradigma alamiah, penelitian ini termasuk dalam jenis kualitatif. Penelitian ini berusaha menggambarkan fenomena pergeseran makna dalam seni tari ndolalak secara utuh dan tidak dimanipulasi. Secara 
operasional penelitian dimulai dari fakta sebagaimana adanya dikumpulkan diklasifikasi, ditafsirkan, dan selanjutnya dianalisa secara induktif-kualitatif.

Sedangkan jika ditinjau dari sumber utama data yang dielaborasi dan dianalisa, penelitian ini termasuk kategori penelitian lapangan (field research). Penelitian ini juga bisa disebut penelitian korelasional karena berusaha mencari hubungan antara variabel bebas (variabel yang mempengaruhi) dan variabel terikat (variabel yang dipengaruhi) dengan menggunakan data lapangan secara kualitatif.

2. Subyek dan Obyek Penelitian

Subyek penelitian ini adalah masyarakat purworejo yang terdiri dari pemangku kepentingan yakni pemerintah kab. Purworejo, pemilik grup tari ndolalak dan masyarakat secara umum termasuk para tokoh agama. Sedangkan obyeknya adalah terdiri dari dua variabel yaitu Pergeseran Makna dalam Kesenian Ndolalak sebagai variabel bebas (yang mempengaruhi) dan Kehidupan Sosial Keagamaan Masyarakat di Purworejo sebagai variabel terikat (yang dipengaruhi)

3. Pendekatan Penelitian

Penelitian sebagai salah satu bentuk kajian keilmuan selalu menuntut adanya pendekatan dalam memahami dan memecahkan suatu masalah. Pendekatan selalu dibutuhkan untuk membantu peneliti agar mudah memahami obyek yang akan diteliti. Penelitian ini menggunakan pendekatan antropologi dan sosiologi . Pendekatan pertama digunakan untuk memahami adanya pergeseran nilai dalam seni tari ndolalak. Pergeseran nilai sebagai fenomena alamiah akan dijelaskan dengan pendekatan ini secara holistik tanpa ada unsur manipulatif. Sedangkan pendekatan kedua digunakan untuk memahami perubahan sosial yang diakibatkan adanya pergeseran nilai tersebut. Melalui pendekatan yang kedua ini peneliti berusaha melihat fenomena sebagai fakta sosial dan memahaminya secara induktif.

4. Teknik Pengumpulan Data

Penelitian ini termasuk jenis penelitian kualitatif dengan pendekatan antropologi dan sosiologi yang digunakan pada segmen masing-masing secar memadai sesuai data dalam obyek penelitian ini sebagaimana diuraikan di atas.

Adapun teknik pengumpulan datanya adalah sebagai berikut:

a. Interview

Operasionalisasi metode ini adalah dengan melakukan tanya 
jawab secara langsung kepada informan/nara sumber untuk mengetahui sejauh mana pemahaman mereka terhadap kesenian ndolalak dan tata nilai yang tersirat di dalamnya. Disamping itu wawancara dilakukan untuk menggali data terkait dengan faktor-faktor yang mempengaruhi terjadinya pergeseran nilai dalam seni tari ndolalak dan implikasinya terhadap kehidupan sosial keagamaan masyarakat Purworejo.

b. Dokumentasi

Metode ini digunakan untuk memperoleh data melalui dokumen dan arsip yang bersifat kepustakaan, misalnya dokumen kependudukan, demografi kabupaten Purworejo, tulisan atau catatan tentang kesenian ndolalak, dan sebagainya. Data dokumen ini digunakan untuk menggali data-data yang tidak bisa diperoleh dengan metode interview.

\section{Instrumen Penelitian}

Instrumen penelitian merupkan perangkat penting dalam pengumpulan data. Ketepatan dalam memilih instrumen menentukan kelengkapan dan keamanan data yang diinginkan oleh peneliti. Dalam penelitian ini peneliti menggunakan instrumen lembar panduan wawancara langsung. Instrumen ini digunakan dalam menggali data melalui wawancara langsung dengan nara sumber yang terdiri dari unsur-unsur yang menjadi subyek penelitian. Hasil wawancara direkam dalam pita kaset dan ditranskrip dalam lembar catatan data hasil wawancara sebagai lembar bantu. Sedangkan untuk mengumpulkan data melalui dokumentasi digunakan instrumen porto folio, baik berupa catatan yang telah terdokumentasi maupun manuskrip-manuskrip terkait dengan obyek penelitian.

\section{Teknik Analisis Data}

Analisis dalam penelitian ini menggunakan analisis induktif, yakni dimulai dari lapangan atau fakta empiris, dengan cara peneliti terjun ke lapangan mencari informasi dari nara sumber tentang realitas kehidaupan masyarakat yang menjadi obyek penelitian. Kemudian realitas tersebut dihubungkan dengan pergeseran nilai dalam seni tari ndolalak.

Pisau analisis yang digunakan adalah teori dialektika Peter L. Berger, dan teori simbol Clifford Geertz. Teori yang pertama untuk menganalisa aspek sosiologi implikasi pergeseran nilai dalam seni tari ndolalak terhadap kehidupan masyarakat purworejo. Sedang teori kedua digunakan untuk mengetahui faktor yang menyebabkan terjadinya pergeseran nilai tersebut. 


\section{Hasil Temuan}

\section{Demografi Purworejo}

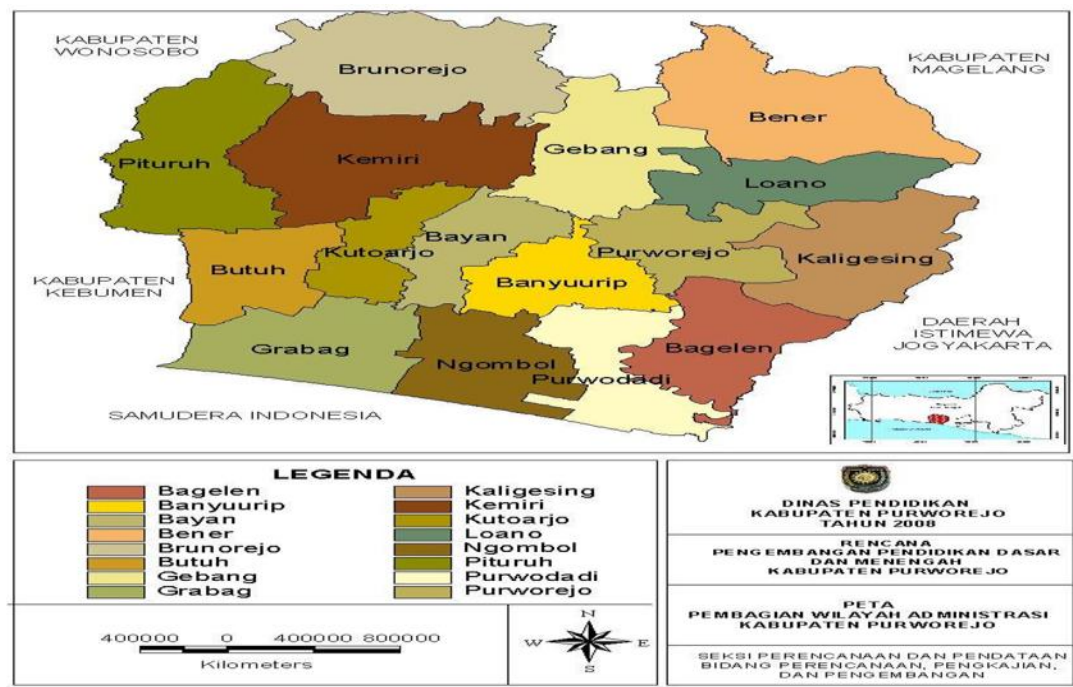

Sumber: $\quad$ http://pdkpurworejo.wordpress.com/2010/04/10/informasigeografis-kabpurl

Berdasarkan peta diatas dapat dijelaskan bahwa kabupaten Purworejo adalah sebuah kabupaten di Provinsi Jawa Tengah. Ibukota berada di kota Purworejo. Kabupaten ini berbatasan dengan kabupaten Wonosobo dan kabupaten Magelang di utara, kabupaten Kulon Progo, provinsi Daerah Istimewa Yogyakarta di timur, Samudra Indonesia di selatan, serta kabupaten Kebumen di sebelah barat.

Bagian selatan wilayah kabupaten Purworejo merupakan dataran rendah. Bagian utara berupa pegunungan, bagian dari Pegunungan Serayu. Di perbatasan dengan Daerah Istimewa Yogyakarta, membujur Pegunungan Menoreh. Purworejo berada di jalur utama lintas selatan Pulau Jawa. Kabupaten ini juga dilintasi jalur kereta api, dengan stasiun terbesarnya di Kutoarjo. Luas wilayahnya $1.091,49 \mathrm{Km}^{2}$ yang dihuni 862.975 Jiwa. Sedangkan wilayah administrasinya terdiri dari 16 kecamatan, 469 desa. 


\section{Sejarah Seni Tari Ndolalak}

Asal mula kesenian ndolalak adalah akulturasi dari budaya Barat (Belanda) dengan Timur (Jawa). ${ }^{40}$ Pada jaman Hindia-Belanda, Purworejo terkenal sebagai daerah basis tentara. Di sana terdapat markas tempat melatih serdadu/tentara Belanda. Sebagaimana tentara pada jamannya, mereka berasal dari berbagai daerah, tidak hanya Purworejo saja tetapi juga dari daerah lain di luar Purworejo dan sekitarnya seperti Magelang, Kebumen, Temanggung, Kulonprogo, Banjarnegara, Purwokerto, dan lain sebagainya. Mereka sengaja didatangkan untuk dilatih oleh tentara/militer Belanda dan hidup di Tangsi (barak tentara). ${ }^{41}$

Ketika mereka hidup di Tangsi tersebut, maka untuk membuang kebosanan, mereka menari dan menyanyi saat malam hari, ada pula yang melakukan pencak silat dan dansa. Gerakan dan lagu yang menarik kemudian menjadi inspirasi pengembangan kesenian yang sudah ada yaitu rebana (kemprang) dari tiga orang pemuda dari dukuh Sejiwan desa Trirejo Kecamatan Loano yaitu Rejo Taruno, Duliyat, Ronodimejo ${ }^{42}$

Diambil dari beberapa sumber bahwa kata dolalak konon masyarakat Purworejo mengatakan bahwa kata dolalak berasal dari bunyi not Do dan La; yakni ucapan notasi lagu yang dinyanyikan oleh para serdadu Belanda dalam Tangsi pada jaman dulu, yang dominan dinyanyikan sambil menari-nari. Unsur-unsur gerak tarian dolalak memang terasa sebagai gerak tari keprajuritan. ${ }^{43}$ Penampilannya sering terucap kata Do- La-La yaitu diambil dari lagu 1 - 6 - 6, yang oleh orang-orang

${ }^{40}$ Dari hasil survey jurusan sejarah FKIP IKIP Semarang (1971) mencatat bahwa akar kesenian ndolalak tumbuh pada masa perang Aceh (1873-1904). Lihat http://novitachizz.wordpress.com/tari-dolalak-khas-purworejo/. Diakses 24-10-2017, Jam 11.02 wib.

${ }^{41}$ Banyak tulisan tentang asal-usul tari dolalak (lidah jawa menucap ndolalak :tambahan " $n$ ” di depan kata) yang di posting pada media elektronik. Masing-masing saling mempengaruhi. Antara lain dapat dilihat http://powerminded.blogspot.com/2013/02/sejarah-asal-mula-keseniandolalak.html\#.VAfiQPRdVhM. Diakses 24-10-2017, Jam 11.02 wib.

${ }^{42}$ Ibid.

${ }^{43}$ Ibid. 
Purworejo yang dekat dengan Tangsi tersebut ditirukan menjadi dolalak, termasuk meniru gerakan dan motif busana yang dipakai para serdadu Belanda pada waktu itu yang akhirnya sampai kini menjadi kesenian rakyat Purworejo. ${ }^{44}$

Dimulai dari desa Kaligoro terus merembes kedaerah Kaligesing dan hampir diseluruh wilayah kecamatan kaligesing, timbul kesenian dolalak. Berangkat dari kecamatan Kaligesing, kesenian dolalak berkembang masuk sampai kota purworejo dan menjadi tontonan / pertunjukan rakyat kota yang menarik dan sangat digemari oleh masyarakat Purworejo. ${ }^{45}$

Awalnya pertunjukan kesenian tersebut tidak diiringi instrumen, namun dengan lagu-lagu vokal yang dinyanyikan silih berganti oleh para penari atau secara koor. Seiring perkembangan zaman dan teknologi, tarian dolalak sekarang sudah diringi dengan musik modern, yaitu keyboard. Lagu-lagu yang dimainkan pun bervariasi dan beragam. ${ }^{46}$

Busana yang dikenakan oleh penarinya terpengaruh nuansa pakaian serdadu Belanda. Ini dapat dilihat dari baju lengan panjang dan celana tanggung dengan warna gelap/hitam, pangkat atau rumbai di bahu dan dada, topi pet dan ada aksesoris yang khas yaitu kacamata hitam. Sampur dipergunakan sebagai pelengkap busana, yang merupakan kebiasaaan orang Jawa dalam melakukan kegiatan menari yang selalu menggunakan sampur/selendang. Penggunaan selendang awalnya hanya di lilitkan pada pinggang namun sekarang sudah menggunakan sampur cendala giri yang diikatkan di depan merupakan alat sabet kanan / kiri lazimnya orang menari. ${ }^{47}$

Penari-penari dolalak bisa mengalami trance, yaitu suatu kondisi mereka tidak sadar atau kesurupan dan pada saat itulah kaca mata hitam di pakai oleh penari tersebut. .Terkadang saat sudah mengalami trance yang
${ }^{44}$ Ibid.
${ }^{45}$ Ibid.
${ }^{46}$ http://oca-sulistya.blogspot.com/2012/04/dolalak-tarian-khas- purworejo.html. Diakses 24-10-2017, Jam 11.04 wib.

${ }^{47}$ Ibid. 
diminta juga aneh-aneh. Misalnya makan kembang, kaca, bara api, dedak (makanan unggas), kemenyan dan minum air kelapa muda. ${ }^{48}$

Jumlah penari rata-rata $12-14$ orang ditambah pengrawit musik sekitar 10 orang. Sebelum kesenian Dolalak mengalami perubahan dan perkembangan, alat musik yang dimainkan hanya berupa 3 rebana (kempreng), kendang, kecer dan bedug atau jidur. Namun, saat ini telah banyak perubahan yang dilakukan oleh seniman-seniman dolalak, baik itu dari lagu, cengkok, tarian sampai iringan musiknya. Alat musik dolalak saat ini juga semakin bertambah banyak. Rata-rata semua Grup Dolalak yang ada di Purworejo sudah menambah alat musiknya dengan keyboard, gitar, bas, cuk, dan drum. Sehingga setiap pementasannya juga mampu menampilkan lagu-lagu dangdut maupun campursari. ${ }^{49}$

Sajian Tari ndolalak menampilkan beberapa jenis tarian yang tiap jenis dibedakan dengan perbedaan syair lagu yang dinyanyikan dengan jumlah 20 sampai 60 lagu. Pada tiap pergantian lagu akan berhenti sesaat sehingga ada jeda tiap ragam geraknya. Sebenarnya cengkok lagu yang ada di ndolalak sangat mudah dipelajari karena syairnya memakai gaya berpantun. Syair lagu menggunakan bahasa Indonesia dan jawa yang romantis, berisi nasehat, sindiran dan pesan-pesan. ${ }^{50}$

Semua lapisan masyarkat se-Kabupaten Purworejo menilai bahwa pertunjukan tarian dolalak merupakan pertunjukan rakyat yang sehat. Karena jika kita amati dengan jeli, di situ ada jurus-jurus pencak silat atau bela diri. Ada gerak pukulan yang tajam mengarah titik-titik lemah lawan, tapi ada juga tangkisan-tangkisan yang menghentak untuk menghindari serangan lawan. Namun, keseluruhan gerak itu tak nampak patah-patah, seperti layaknya sebuah gerakan kanuragan. Masyarakat dan pemerintah senantiasa berupaya melestarikan, mengembangkan, meningkatkan, dan

${ }^{48}$ Depdikbud Propinsi Jateng, Deskripsi Kesenian Dolalak, hlm 42.

49 Ibid. hlm. 16. Juga hasil Wawancara dengan Ibu Utariningsih, Pamong Budaya Dikbudpora kabupaten Purworejo.

50 Wawancara dengan Bapak Adi Warno pemilik grup dolalak "Sri Mulyo" Mlaran. 
menyebarluaskan kesenian dolalak sesuai dan selaras dengan kemajuan jaman. $^{51}$

Sebagai tari rakyat, kesenian dolalak merupakan sarana dan media pengumpulan masa, sekaligus sebagai hiburan yang sehat, murah dan meriah. Hingga saat ini pengembangan tarian tradisional Dolalak tidak saja di kelompok tari/grup. Pemerintah Kabupaten Purworejo melalui Dinas Pendidikan dan Kebudayaan melakukan pembinaan dan pelatihan hingga sekolah-sekolah di seluruh Kabupaten Purworejo. Bahkan telah dipentaskan secara massal oleh siswa pada Peringatan Hari Pendidikan Nasional Tahun 2009 di Alun-alun Purworejo dan seluruh Kecamatan seKabupaten Purworejo dengan jumlah peserta 2.100 anak di Alun-alun dan sekitar 16.000 siswa di semua kecamatan.

Faktor pendukung dari adanya tarian dolalak wanita adalah baik kalangan pejabat, perangkat, kaya, miskin, agama, umur, pedagang, petani, remaja, pelajar, mahasiswa, laki - laki, wanita sangat menyukai tari dolalak tersebut. Sedang kalau dilihat dari faktor penghambat dari masyarakat sangat tipis karena pertunjukan kesenian dolalak sangat diminati penonton bahkan kuat sampai semalam suntuk sama halnya dengan wayang kulit

\section{Nilai dalam Kesenian Ndolalak}

Dalam sebuah tarian antara tubuh, gerak komposisi tari tidak dapat dipisahkan.Dalam sebuah tarian terdapat unsur-unsur yang membangunnya yakni unsur gerak, tenaga dan waktu. Gerak didalam tarian bukanlah gerak seperti dalam kehidupan sehari-hari. Gerak tari adalah gerak yang telah mengalami perubahan atau proses stilasi dari gerak wantah (asli) ke gerak murni dan gerak maknawi. ${ }^{52}$

Gerak wantah yang telah mengalami stilasi itu akhirnya dapat dilihat dan dinikmati karena menjadi gerakan yang memiliki nilai estetik

${ }^{51}$ Dalam hal dukungan pemerintah kepada pemilik grup tari ndolalak dalam mengembangkan seni tersebut beragam. Pak Narto Narimo mengatakan dukungan pemerintah tidak ada. Pemerintah hanya mengakui dan tidak memberi bantuan apapun. Pernah ia mengajukan bantuan tetapi tidak cair, katanya. Wawancara dengan bapak Narto Narimo, pemilik grup dolalak "Sri Arum” Mlaran.

${ }^{52}$ http://materisenibudayablog.blogspot.com/2010/12/unsur-dasar-dankomposisi-tari.html. Diakses 24-10-2017, Jam 11.06 wib. 
(gerak murni dan gerak gerak maknawi). Gerak wantah contohnya mencangkul, membatik dll.gerak wantah mudah dipahami sebalikknya gerak murni dan maknawitidak mudah dipahamikarena sudah mengalami proses stilisasi atau perubahan baik penambahan dan pengurangan. Gerak murni merupakan gerak wantah yang telah diubah menjadi gerak yang indah namun tak bermakna. Gerak maknawi adalah gerak wantah merupakan gerak yang telah diubah menjadi gerak indah yang bermakna. ${ }^{53}$

Unsur berikutnya dalam tari adalah unsur gerak. Penggunaan tenaga dalam gerak tari meliputi:

a. Intensitas berkaitan dengan kuantitas tenaga dalam tarian yang menghasilkan tingkat ketegangan gerak

b. Aksen/tekanan muncul ketika gerakan dilakukan secara tiba-tiba dan kontras

c. Kualitas berkaitan dengan cara penggunaan atau penyaluran tenaga. ${ }^{54}$

Unsur yang tidak kalah pentingnya adalah ruang. Unsur ruang yang dimaksudkan sebagai unsur tari terbagi dua yakni ruang yang diciptakan oleh penari dan ruang pentas atau ruang tempat penari melakukan gerak. Ruang yang diciptakan penari adalah ruang yang dibatasi oleh imajinasi penari berupa jarak yang terjauh yang dapat dijangkau oleh tangan dan kakinya dalam posisi tidak pindah tempat. Ruang pentas adalah arena yang digunakan oleh penari yang biasa disebut dengan panggung, lapangan atau halaman terbuka. ${ }^{55}$

Unsur yang terakhir dalam seni adalah waktu. Dalam unsur waktu juga menentukan dalam membangun gerak tari. Dalam unsur waktu ada 2 faktor yang sangat penting yaitu ritme dan tempo. Ritme dalam gerak tari menunjukkan ukuran waktu dari setiap perubahan detail gerak, ritme lebih mengarah pada ukuran cepat atau lambat setiap gerakan yang dapat dicapai ${ }^{56}$
${ }^{53}$ Ibid.
${ }^{54}$ Ibid.
${ }^{55}$ Ibid.
${ }^{56}$ Ibid 
Dansa (tari gaul gaya Barat) dengan iringan lagu membangkitkan inspirasi beberapa warga pribumi untuk menirunya menjadi tari dolalak. Menurut penelitian Prihatini (2000) nama mereka adalah Rejotaruno, Duliyat dan Ronodimejo untuk menirunya. Pada awalnya tari itu untuk menghibur diri pasukan Belanda yang ditugaskan di Aceh membuat tari keprajuritan, dengan barisan dan cakepan atau nyanyian yang berbentuk "pernesan" atau sindiran serta dengan pakaian ala Belanda dan Perancis. Ketika Purworejo menjadi basis militer Belanda kesenian itu juga makin berkembang luas. Menurut salah satu sumber di internet (javapromo.com, 2007) yang dikemukakan oleh Tijab pimpinan group dolalak dusun Giri Tengah Borobudur mengatakan bahwa dolalak berasal dari kata "Duh Allah" dan lahirnya seni dolalak karena adanya kisah pasukan Srikandi yang membantu Nyai Ageng Serang pada saat perang Diponegoro. Pasukan wanita tersebut berada di bawah pimpinan Ambarsari dan Roro Ayu Tunggalsari. ${ }^{57}$

Jika data tersebut dapat diterima, maka dapat dipahami bahwa sejarah tentang asal-usul tari dolalak (ndolalak: logat jawa) ada tiga versi. Versi pertama menyebutkan tari itu berasal dari tarian serdadu Belanda yang ada di Tangsi Tentara di Purworejo dengan notasi lagu 1-6-6 (do-la-la) lalu ditirukan oleh masyarakat di sekitar tangsi menjadi ndolalak. Versi kedua yaitu hasil penelitian Prihatini, tari itu berasal dari tarian yang diciptakan oleh serdadu Belanda yang ditugaskan di Aceh. Versi ketiga bersumber dari Tijab mengatakan bahwa asal-usul nama dolalak bukan dari notasi do-la-la tetapi dari "Dub Allaab". Versi ketiga ini nampak sekali campuran atau pengaruh nilai Islam sudah muncul dalam seni tersebut. Namun berdasarkan telaahan peneliti seluruh nara sumber yang peneliti wawancarai mengatakan sesuai dengan versi yang pertama.

3. Faktor-faktor Penyebab Pergeseran Nilai dalam Seni Tari Ndolalak

a. Faktor Intrinsik

Yang dimaksud dengan faktor intrinsik adalah faktor atau pengaruh yang datang dari dalam. ${ }^{58}$ Faktor intrinsik itu terdiri dari faktor

57 Titel: "Tari Dolalak Khas Purworejo" dalam http://novitachizz.wordpress.com/tari-dolalak-khas-purworejo/. Diakses 24-10-2017, Jam 11.09 wib.

58 http://id.wiktionary.org/wiki/faktor_intrinsik. Diakses 24-10-2017, Jam 11.11 wib. 
yang tidak tampak kasat mata tetapi dapat dirasakan. Faktor ini terdiri dari keindahan (beauty), gerakan dan makna dalam lirik lagu yang mengiringi tarian sebagai pembawa misi. Faktor ini melekat pada seni teri tersebut sebagai produk budaya hasil kreasi manusia. Pada awalnya ketika tari dolalak dimainkan oleh penari pria keindahan tidak menjadi faktor utama yang menjadi perhatian dan dan daya tarik dari seni itu, tetapi yang menjadi daya tariknya adalah nilai keprajuritan yang terfragmentasikan oleh penari pria ala serdadu Belanda.

Namun dalam perkembangannya, tepatnya pada tahun 1980-an terjadi pergeseran dari semula penarinya hanya laki-laki kini perempuan juga bisa menjadi penari. Kenyataannya justru penari perempuan menjadi daya tarik tersendiri, karena yang lebih suka dengan hiburan tari ini adalah kaum laki-laki. Ini menunjukkan bahwa keindahan telah menggeser perhatian penikmat seni tari. Sebagaimana dikatakan oleh Utariningsih selaku Pamong Budaya di Dinas Kebudayaan Pendidikan dan Olah Raga kabupaten Purworejo.

b. Faktor Ekstrinsik

Faktor ekstrinsik adalah segala faktor luar yang melatarbelakangi penciptaan karya sastra. Ia merupakan milik subjektif pengarang yang bisa berupa kondisi social, motivasi (motivation), dan keinginan (mood), tendensi yang mendorong dan mempegaruhi kepengarangan seseorang. Faktorfaktor ekstrinsik itu dapat meliputi:

1) tradisi dan nilai-nilai,

2) struktur kehidupan sosial,

3) keyakinan dan pandangan hidup,

4) suasana politik,

5) lingkungan hidup,

6) agama, dan sebagainya ${ }^{.59}$

Pada awal kehadirannya sampai tahun 1970 dolalak merupakan kesenian rakyat yang berfungsi sebagai penghibur pada kegiatan hajatan masyarakat desa. Pada dekade 1970 ketika pemerintah mulai menggalakkan kesenian daerah sebagai aset wisata, dan mulai ada campur tangan dari pemerintah dan pembinaan. Atas prakarsa Bupati Soepanto (1975) yang menganjurkan kaum wanita bisa menjadi penari dolalak

$59 \quad$ http://rizkywulancils.blogspot.com/2011/05/unsur-intrinsik-danekstrinsik.html. Diakses 24-10-2017, Jam 11.14 wib. 
mendapat respon yang positif. Sehingga mulailah muncul group-group dolalak di tingkat kecamatan dan mencapai puncaknya pada dekade 1980 an. Bahkan pada tahun 80 -an terjadi perubahan yang menonjol dimana kemudian para penari yang tadinya lelaki diganti menjadi wanita yang diawali dengan group dolalak dari dusun Teneran, desa Kaligono, kecamatan Kaligesing. Dan kemudian pada saat ini berkembang pesat group dolalak yang penarinya wanita. ${ }^{60}$

Salah satu faktor yang mendorong perubahan penari dari kuam laki-laki ke kaum perempuan lebih dikarenakan alasan ekonomi dan juga alasan pasar, bukan semata-mata alasan fungsional seni sebagai hiburan. Dalam kontek ini pasarlah yang menentukan, sehingga tarian tersebut akan bermetamorfosis dari segi tampilannya mengikuti selera pasar. Salah satu selera pasar adalah bahwa penonton yang mayoritas laki-laki merasa lebih tertarik jika penarinya perempuan. ${ }^{61}$

Disamping faktor tersebut, intervensi pemerintah dalam hal ini adalah Soepanto selaku bupati Purworejo merupakan faktor yang nyatanya mempengaruhi pergeseran tersebut. Lebih-lebih ketika musik dangdut dan solo organt telah merambah dunia hiburan rakyat, muncul pengaruh yang nyata terhadap penampilan lagu-lagu yang ditampilkan untuk mengiringi tari dolalak. Awalnya syair berupa tembang-tembang Jawa baik yang bernuan romantis, erotis maupun bernuansa nasehat. Namun setelah terjadi akulturasi antara musik Jawa dengan musik dangdut modern dengan tembang-tembang bebas, dangdut campursari dengan tembang campuran Indonesia-Jawa, kini syair yang dilantunkan dalam tarian tersebut menjadi campur-campur dan cenderung mengabaikan pakemnya, bahkan sekarang ada saweran. ${ }^{62}$

4. Implikasi Pergeseran Nilai dalam Kehidupan SosialKeagamaan Masyarakat di Purworejo

a. Implikasi Sosial

${ }^{60}$ Ibid.

${ }^{61}$ Wawancara dengan ibu Utariningsih, Pamong Budaya Dikbudpora Kabupaten Purworejo.

${ }^{62}$ Wawancara dengan Bapak Sumaryo, Pemilik Grup Bhinneka Karya Mlaran, Gebang, Purworejo. 
Sebagaimana di jelaskan dalam landasan teori bahwa pergeseran nilai dalam sebuah produk budaya yang diciptakan oleh manusia mempunyai implikasi sosial. Implikasi sosial itu terjadi karena adanya kontak dan dialektika antara manusia dan produk kreasinya. Implikasi itu tampak ketika berada pada tahapan internalisasi. Pergeseran nilai baik yang disebabkan oleh faktor intrinsik maupun ekstrinsik dapat dilihat pengaruhnya terhadap kehidupan sosial masyarakat purworejo.

Pergeseran intrinsik dalam tari ndolalak sebagaimana disebutkan dalam sub bab sebelumnya adalah terdiri dari tiga faktor yaitu keindahan (beauty), gerakan dan makna dalam lirik lagu yang mengiringi tarian sebagai pembawa misi. Faktor keindahan dalam tari tersebut pada awal penciptaannya (menurut versi yang mengatakan berawal dari serdadu Belanda yang bertugas di Aceh) terdapat pada pengetahuan dan makna tentang keprajuritan. Kini keindahan itu telah bergeser menjadi keindahan formal yang tampak kasat mata dan berfungsi sebagai hiburan sematamata. Implikasi sosialnya adalah bahwa masyarakat tidak lagi bisa mengenal arti perjuangan dari pertunjukan tari tersebut melainkan hanya menikmati keindahan formal. Akibatnyua mereka para penikmat seni cenderung menjadi hidonis.

Pergeseran dalam hal makna syair lagu tampak pada materi lagu yang dinyanyikan. Awalnya ketika tari tersebut dikreasi oleh tiga orang santri bersaudara yaitu Rejotaruno, Duliyat, dan Ronodimejo, syairnya bernada nasehat dan Islami karena diisi selawatan. Kini nyanyiannya sudah berubah mengikuti permintaan pasar. Implikasi sosialnya adalah masyarakat terbelah menjadi dua yakni sebagian mereka setuju adanya seni tersebut dan sebagian yang lain khususnya kaum santri menjadi tidak setuju dan cenderung mengharamkan. Jadi ndolalak yang semestinya menjadi media berkumpul dan berssosialisasi seluruh masyarakat Purworejo berubah menjadi sekedar tontonan yang menghibur bagi penggemarnya.

Sedangkan implikasi sosial yang ditimbulkan dari pergeseran nilai yang diakibatkan faktor ekstrinsik dapat dilihat dari berubahnya penari laki-laki menjadi perempuan. Perubahan yang terjadi pada 1980-an tersebut akibat prakarsa Bupati Supanto yang kemudian ditangkap oleh para pemilik grup ndolalak. Lalu jadilah sampai sekarang hampir semua grup ndolalak penarinya wanita. Implikasi positifnya adalah masyarakat kaum wanita menjadi terberdayakan. Pada titik ini ada senangat kesetaraan 
gender dengan mengangkat derajat wanita pada level yang seimbang dengan laki-laki dalam hal peran sosialnya. Dengan demikian ndolalak tidak semata-mata milik kaum laki-laki sebagai pelaku dan sekaligus penikmat, tetapi wanita juga bisa ikut mengambil peran.

Ketika kesenian ini telah terinternalisasi dalam diri masyarakat Purworejo, rasanya dalam tata kehidupan masyarakat tidak terpisahkan dengan kesenian ini. Akibatnya muncul rasa ikut memiliki terhadap kesenian tersebut, bahkan pada setiap perhelatan rasanya kurang mantap/afdol dan kurang meriah jika belum dipentaskan kesenian ndolalak. Dengan demikian kemudian memotivasi para remaja untuk menjadi penari ndolalak dengan alasan hiburan dan ekonomi. Menjadi penari berarti menambah penghasilan karena setiap manggung mereka mendapat bayaran dari pihak pengundang. Di sinilah implikasi positif dalam hal peningkatan ekonomi masyarakat menjadi kenyataan.

b. Implikasi Keagamaan

Hampir bisa dipastika setiap hal yang mempunyai implikasi sosial juga mempunyai implikasi keagamaan. Mengapa, karena norma agama menjangkau pada prilaku sosial manusia. Oleh karenanya, melihat pengaruh pergeseran makna dalam seni tari ndolalak terhadap kehudupan keagamaan masyarakat Purworejo tidak bisa terlepas dari perhatian pada aspek sosial.

Pada awalnya seni tari hasil akulturasi budaya Barat dan Islam itu berfungsi sebagai sarana dakwah dan juga sarana hiburan rakyat. Sebagai sarana dakwah karena syairnya berisi nasehat dan tampak Islami ketika syair yang dilantunkan adalah syair selawat. Ketika sekarang syair itu tidak lagi demikian tetapi sudah menjadi campuran dangdut, pop, dan campursari, yang tentu tidak selalu berisi nasehat, tetapi cenderung romantis, maka misi yang disampaikan melalui kesenian tersebut menjadi bergeser pula. Ketika syair yang dilantunkan mengikuti permintaan pasar (pengundang), maka pasarlah yang menentukan misi dalam kesenian tersebut. Dengan demikian implikasi keagamaan yang diakibatkan bergesernya misi dakwah menjadi misi hiburan sangat dipengaruhi oleh faktor eksternal yakni pengundang dan selera masyarakat.

Perubahan itulah yang sesungguhnya, menurut hemat peneliti, mengakibatkan munculnya fatwa MUI Purworejo pada tahun 1985 tentang haramnya kesenian tari ndolalak. Pertimbangan yang digunakan dalam fatwa tersebut adalah faktor formal bukan faktor ide, pengetahuan, 
dan substansi kesenian tersebut. Hal itu terbukti dari argumentasi yang dikemukakan yakni keharaman kesenian tersebut karena menampilkan aurat dan lenggak-lenggok tubuh wanita di depan orang lain. Yang demikian ini adalah haram menurut hukum Islam. Implikasi keagamaan ini kemudian memunculkan stigma bahwa kesenian ndolalak bukan kesenian Islami tetapi kesenian hiburan rakyat yang fungsinya semata-mata untuk menghibur.

\section{Kesimpulan}

Pertama, terjadi pergeseran nilai dalam seni tari ndolalak karena adanya tarik menarik antara etika/norma dan estetika dalam memahami seni. Akibatnya terjadi perubahan secara fungsional. Awalnya ketika masih menjadi tarian serdadu Belanda hanya berfungsi sebagi hiburan untuk mengisi waktu istirahat setelah berlatih.

Setelah tarian tersebut ditirukan oleh masyarakt di sekitar tangsi tempat serdadu itu, lalu muncul gagasan dari tiga santri yakni Rejo Taruno, Duliyat, Ronodimejo untuk mengkereasi tarian tersebut yang dikombinasi dengan lagu-lagu selawatan. Pada tahapan ini ndolalak berfungsi sebagai media dakwah.

Namun belakangan sejak tahun 1080-an ketika penari ndolalak berubah dari yang tadinya hanya laki-laki menjadi perempuan, kesenian tersebut kembali menjadi berfungsi sebagai hiburan rakyat semata, sehingga kesenian ndolalak disebut sebagai kesenian rakyat. Walaupun demikian pada saat itu masih mengandung misi nasehat meskipun tidak berbanding lurus dengan pakaian yang dikenakan oleh penarinya (celana pendek di atas lutut).

Kondisi terakhir ketika penelitian ini dilakukan telah tejadi pergeseran berikutnya yaitu bahwa penampilan ndolalak cenderung mengikuti pasar dalam hal ini adalah para penanggap, sehingga lagu yang dilantunkan sudah tidak lagi mengikuti pakemnya tetapi semata-mata untuk mengikuti permintaan. Akibatnya tidak ada pesan positif yang bisa disampaikan melalui kesenian ini kecualai hanya sebagai hiburan saja untuk memuaskan penontonnya. Namun sisi positifnya adalah dapat meningkatkan ekonomi orang yang tergabung dalam grup kesenian maupun masyarakat pedagang kecil yang menjajakan dagangannya setiap kali ada event pertunjukan kesenian tersebut. 
Kedua, ada 2 faktor yang memengaruhi pergeseran nilai tersebut yaitu:

1. Faktor Intrinsik terdiri dari:

a. SDM (kreator awal: serdadu Belanda, Bangilun:santri, pemilik group)

b. Keindahan (beauty), gerakan dan makna dalam lirik lagu yang mengiringi tarian sebagai pembawa misi

2. Faktor Ekstrinsik terdiri dari:

a. Ekonomi (selera pasar)

b. Dinamika sosial

c. Paham keagamaan

d. Intervensi Pemerintah

e. Maraknya musik orgen tunggal dan dangdut

Ketiga, implikasinya dalam kehidupan sosial-keagamaan masyarakat di Purworjo adalah sebagai berikut:

1. Ndolalak menjadi kurang diminati masyarakat santri setelah ada fatwa haram dari MUI kab. Purworejo 1985,

2. Muncul fatwa rambu-rambu pakaian penari yaitu pakai stoking panjang, baju panjang sampai bawah lutut dan tidak ketat

3. Intervensi pemerintah agar ada penyeimbangan antara etika dan estetika supaya tidak tidak terjadi penolakan dari pihak masyarakat santri.

\section{Referensi}

Agus, "Awal Mula Tarian Dolalak", dalam bttp:// bloggerpurworejo.com/2009/02/ awal-mula-tarian-dolalak/. Diakses pada tanggal 24 Oktober 2017

Ali, Sayuthi, Metodologi Penelitian Agama, Pendekatan Teori dan Praktek, cet. I, Jakarta:PT. Raja grafindo Persada, 2002.

Artanti, Theo, "Analisis Bentuk dan Nilai Kesenian Ndolalak Putri "Dwi Lestari" Desa Plipir Kecamatan Purworejo Kabupaten Purworejo", dalam "ADITYA - Pendidikan Bahasa dan Sastra Jawa" dalam http:// ejournal.umpwr.ac.id/index.php/aditya/article/view/695. Diakses pada tanggal 24 Oktober 2017 
Asad, Talal, "The Construction of Religion as an Antropological Category", dalam Michael Lambek (ed.), A Reader in The Antropology of Religion, cet. III, Australia: Blackwell Publishing, 2005.

Ayrookuzhiel, A.M. Abraham, "Agama, Spiritualitas dan Aspirasi Rakyat", dalam Th. Sumartana dkk., Spiritualitas Baru: Agama dan Aspirasi Rakyat, cet. I, Yogyakarta: Peberbit Institut Dian/Interfidei, 1994.

Baedhowi, Humanisme Islam: Kajian terbadap Pemikiran Filosofis Muhammad Arkoun, cet. I, Yogyakarta: Pustaka Pelajar, 2008.

Berger, Peter L., Terj. Hartono, Langit Suci Agama Sebagai Realitas Sosial, cet. II, Jakarta: PT. Pustaka LP3ES, 1994.

Ess, Josep van, "Muhammad an The Qur'an Propehecy and Revelation: Islamic Perspectives", dalam Hans Kung, terj. Peter Heinegg, Christianity and the World Religions: Paths of Dialogue with Islam, Hinduisme, and Buddism, USA: Willian Collins Sons \& Co., Ltd and Doubleday Inc., 1986.

Greetz, Glifford, Religion of Java, Chicago: University of Chicago Press, 1976.

Hasan Bisri, Cik, Pilar-pilar Penelitian Hukum Islam dan Pranata Sosial, cet. I, Jakarta: PT. Raja Grafindo Persada, 2004.

Hasan, Ridwan, "Seni Seudati: Media Edukasi Sufistik dalam Mengembangkan Nilai Socio-Religius Masyarakat Aceh", dalam alTahrir Jurnal Pemikiran Islam, Vol. 13, No. 1 Mei 2013.

Hidayat, Komaruddin, Tragedi Raja Midas, Moralitas Agama dan Krisis Modernisme, cet. I, Jakarta: Penenrbit Paramadina, 1998.

http //mgmpseni. wordpress.com/'maten-belajar/senj-rupa/semester-1 /kelas- vii/pengertian-seni/. Diakses pada tanggal 24 Oktober 2017

http //www.purworejokab.go.id/potensi-unggulan/s.ensi-seni-budayandolalak. Diakses pada tanggal 24 Oktober 2017

http://www.shdcshare.net/evertstaasiringan/pengaruh-kebudayaanterhadap-perilaku-masyarakat-alaud1. Diakses pada tanggal 24 Oktober 2017 
http://www.hdcshare.net/evertstaasiringan/pengaruh-kebudayaanterhadap-perilaku-masyarakat-alaud10. Diakses pada tanggal 24 Oktober 2017

http://id.wikipedia.org/wiki/Budaya\#Definisi Budaya. Diakses pada tanggal 24 Oktober 2017

http://id.wikipedia.org/wiki/Kabupaten Purworejo/Perekonomian. Diakses pada tanggal 24 Oktober 2017

http://id.wikipedia/org/wiki/Budaya/Pengertian kebudayan. Diakses pada tanggal 24 Oktober 2017

http://id.wiktionary.org/wiki/faktor intrinsi. Diakses pada tanggal 24 Oktober 2017

http://materisenibudayablog.blogspot.com/2010/12/unsur-dasar-dankomposisi-tari.html. Diakses pada tanggal 24 Oktober 2017

http://novitachizz.wordpress.com/tari-dolalak-khas-purworejo/. Diakses pada tanggal 24 Oktober 2017

http://oca-sulistya.blogspot.com/2012/04/dolalak-tarian-khaspurworejo.html. Diakses pada tanggal 24 Oktober 2017

http://pamanahan.blogspot.com/. Diakses pada tanggal 24 Oktober 2017

http://pena-batang.blogspot.com/2009/05/penafsiran-penulis-tentangnama-nama.html. Diakses pada tanggal 24 Oktober 2017

http://pesonakaligono.blogspot.com/2014/08/gerak-rancak-taridolalak.html. Diakses pada tanggal 24 Oktober 2017

http://powerminded.blogspot.com/2013/02/sejarah-asal-mula-keseniandolalak.html. Diakses pada tanggal 24 Oktober 2017

http://rizkywulancils.blogspot.com/2011/05/unsur-intrinsik-danekstrinsik.html. Diakses pada tanggal 24 Oktober 2017

http://www.bimbingan.org/arti-dari-sawer.htm. Diakses pada tanggal 24 Oktober 2017

http://www.majalahpendidikan.com/2011/04/pengertian-dan-konsepnilai-dalam-islam.html. Diakses pada tanggal 24 Oktober 2017 
https://karyatulisilmiah.com/pengaruh-budaya-terhadap-lingkungan/. Diakses pada tanggal 24 Oktober 2017

Ismail, Faisal, Pijar-pijar Islam, Pergumulan Kultur dan Struktur, cet. I, Yogyakarta: LESFI, 2002.

Kattsoff, Louis O., Terj. Soejono Soemargono, Pengantar Filsafat, cet. IX, Yogyakarta: Tiara wacana Yogya, 2004.

Kemiran, "Peran Tokoh Agama dan Tokoh Masyarakat dalam Mempertahankan Seni Dolalak di Desa Seren Kecamatan Gebang Kabupaten Purworejo", Skripsi, dalam PERPUSDIGITAL PPKN, Edisi Agustus 1, 2012 dalam http://perpusdigitalppkn.wordpress.com/2012/08/01/perantokoh-agama-dan-tokoh-masyarakat-dalam-mempertahankan-senidolalak-di-desa-seren-kecamatan-gebang-kabupaten-purworejo/. Diakses pada tanggal 24 Oktober 2017

Koentjaraningrat, Kebudayaan Jawa, Jakarta Balai Pustaka. 1984.

, Pengantar Ilmu Antropologi, cet. VIII, Jakarta: PT. Rineka Cipta, 1990.

Machasin, Islam Dinamis Islam Harmonis Lokalitas, Pluralisme, Terorisme, cet.I, Yogyakarta: LKiS, 2012.

Mahsun, "Bermazhab Secara Manhaji dan Implementasinya dalam Bahsul Masail Nahdlatul Ulama Tingkat Nasional”, Disertasi, Yogyakarta: UIN Sunan Kalijaga, 2013.

Mayasari, Ratna, "Eksistensi Kesenian Dolalak Sebagai Kebudayaan Daerah di Desa Mlaran Kecamatan Gebang Kabupaten Purworejo", Skripsi, Surakarta: UNS - FIKIP Jur P.PS-K84080972012., dalam http://dgilib.uns.ac.id/pengguna._Diakses pada tanggal 24 Oktober 2017

Nata, Abuddin, Metodologi Studi Islam, cet. I, Jakarta: PT. Raja Grafindo Persada, 1998

Penyusun Al-Qur'an dan Terjemahnya, al-Qur'an al-Karim wa Tarjamatu Ma'ànīi ilā al-Lugah al-Indüisiah, Kudus: Menara Kudus, 1997. 
Pritchard, Evans, Teori-teori tentang Agama Primitif, cet. I, Yogyakarta: Bagian Penerbitan PLP2M, 1984.

Rahman, Budhy Munawar, Islam Pluralis, cet. I, Jakarta: PT. Raja Grafindo Persada, 2004.

Rolston, Holmes, Science and Religion, cet. I, USA: Random house, Inc, 1987.

Setiady, David Ardes, "Pengaruh Seni Dalam Hidup Manusia" dalam bttp://proaktif-online.blogspot.com/2013/12/pikir-pengarub-seni-dalambidup-manusia.btml

Suriasumantri, Jujun S., Filsafat Ilmu Sebuah Pengantar Populer, cet. XVII, Jakarta: Pustaka Sinar Harapan, 2003.

Syam, Nur, Mad₹̧hab-madzৃhab Antropologi, Yogyakarta: LKiS, 2012.

Tim Penyusun, Deskripsi Kesenian Dolalak, Semarang: Deartemen pendidikan dan Kebudayaan, 1992.

Wijayanto, Ne.u, "Pengaruh Budaya Terhadap Lingkungan", dalam bttp:/ / newijayanto.blogspot.com/2012/04/pengarub-budaya-terbadaplingkungan.htm. Diakses pada tanggal 24 Oktober 2017

Yusuf, Djauhariyah, "Studi tentang Upacara Naik Ayun Anak sebagai Perwujudan Percampuran Adat Orang Banjar dan kebudayaan Islam di Kota Madya Samarinda", dalam M. Rosyid Fauzi \& M. Nasir (eds), Sinopsis Hasil-basil Penelitian Badan Litbang dan Diktat Departemen Agama RI, Jakarta: Badan Litbang dan Diklat Departemen Agama RI, 2007. 